${ }^{8}$ Remuzzi G, Livio M, Roncaglioni MC, Mecca G, Donati MB, de Gaetano G. Bleeding in renal failure: is von Willebrand factor implicated ? $\mathrm{Br}$ Med f 1977;ii:359-61.

${ }^{9}$ Remuzzi G, Bertani T, Mecca G, Donati MB, de Gaetano G. Factor VIII-related protein on vascular intima of patients with chronic renal failure and prolonged bleeding times. $B r \operatorname{Med} F$ 1978; :70-2.

10 Warrell RP, Hultin MB, Coller BS. Increased factor VIII/von Willebrand factor antigen and von Willebrand factor activity in renal failure. $A m \mathcal{F}$ Med $1979 ; 66: 226-8$

11 Ruggeri ZM. Endothelium, factor VIII/von Willebrand factor, and renal diseases. In: Remuzzi G, Mecca G, de Gaetano G, eds. Hemostasis, prostaglandins, and renal disease. New York: Raven Press, 1980:11-20.

12 Laurell C-B. Electroimmuno assay. Scand $\mathcal{F}$ Clin Lab Invest $1972 ; 29$, suppl 124:21-37.

${ }^{13}$ Denson KWE. The ratio of factor VIII-related antigen and factor VIII biological activity as an index of hypercoagulability and intravascular coagulation. Thromb Res 1977;10:107-19.

14 Clauss A. Gerinnungsphysiologische Schnellmethode zur Bestimmung des Fibrinogens. Acta Haematol (Basel) 1957;17:237-46.

16 Bloom AL. Factor VIII-related protein in renal failure with prolonged bleeding time. Br Med f 1978;i:306.

16 Wautier JL, Nurden AT, Michel H, Caen JP. Defective ristocetin aggregation not attributable to a von Willebrand or Bernard-Soulier type defect. Thromb Haemostas $1977 ; 38: 4$.

17 Gotch FA. A quantitative evaluation of small and middle molecule toxicity in the therapy of uraemia. Dialysis and Transplantation 1980;9:183-94.

18 Lindsay RM, Moorthy AV, Koens F, Linton AL. Platelet function in dialyzed and non-dialyzed patients with chronic renal failure. Clin Nephrol $1975 ; 4: 52-7$.

19 Remuzzi G, Livio M, Marchario G, Mecca G, de Gaetano G. Bleeding in renal failure: altered platelet function in chronic uraemia only partially corrected by haemodialysis. Nephron $1978 ; 22: 347-53$

20 Turney JH, Woods HF, Weston MJ. Regular haemodialysis therapy induces a prothrombotic state. Thromb Haemostas 1979;42:67.

${ }^{21}$ Ross R, Glomset JA. The pathogenesis of atherosclerosis. $N$ Engl f Med $1976 ; 295: 369-77,420-25$.
${ }^{22}$ Fuster V, Bowie EJW, Lewis JC, Fass DN, Owen CA, Brown CL. Resistance to arteriosclerosis in pigs with von Willebrand's disease. $\mathcal{F}$ Clin Invest $1978 ; 61: 722-30$.

${ }^{23}$ Redman CWG, Denson KWE, Beilin LJ, Bolton FG, Stirrat GM. Factor VIII consumption in pre-eclampsia. Lancet 1977;ii:1249-52.

24 Turney JH, Williams LC, Fewell MR, Parsons V, Weston MJ. Platelet protection and heparin sparing with prostacyclin during regular dialysis $\widehat{\triangle}$ therapy. Lancet $1980 ;$ ii :219-22.

${ }^{25} \mathrm{Jaffe}$ EA. Endothelial cells and the biology of factor VIII. $N$ Engl $\mathcal{F}$ Med 1977:296:377-83.

${ }^{26}$ Nachman R, Levine R, Jaffe EA. Synthesis of factor VIII antigen by $\mathbb{D}$ cultured guinea pig megakaryocytes. $\mathcal{F}$ Clin Invest 1977;60:914-21.

27 Weston MJ, Woods HF, Turney JH. Antiplatelet agents and extracorporeal $\varrho$ circulation. Int $\mathcal{F}$ Artif Organs $1980 ; 3: 129-32$.

${ }^{28}$ Bricker NS. On the pathogenesis of the uremic state: an exposition of the "trade-off"' hypothesis. N Engl I Med 1972;286:1093-9.

${ }^{29}$ Mannucci PM, Pareti FI, Holmberg L, Nilsson IM, Ruggeri ZM. Studies on the prolonged bleeding time in von Willebrand's disease. $\mathcal{F}$ Lab Clin Med 1976;88:662-71.

30 Weiss HJ, Tschopp TB, Baumgartner HR, Sussmann II, Johnson MM, Egan JJ. Decreased adhesion of giant (Bernard-Soulier) platelets to subendothelium. Further implications on the role of the von Willebrand factor in hemostasis. Am $\mathcal{F}$ Med 1974 ;57:920-5.

31 Jenkins CSP, Phillips DR, Clemetson KJ, Meyer O, Larrier MJ, Luscher $\vec{\circ}$ EF. Platelet-membrane glycoproteins implicated in ristocetin-induced aggregation. Studies of the proteins of platelets from patients with $\omega$ Bernard-Soulier syndrome and von Willebrand's disease. 7 Clin Invest 1976;57:112-24

32 Janson PA, Jubelirer SJ, Weinstein MJ, Deykin D. Treatment of the bleeding tendency in uremia with cryoprecipitate. $N$ Engl $f$ Med $1980 ; 303: 1318-22$.

${ }^{33}$ Lindner A, Charra B, Sherrard DJ, Scribner BH. Accelerated atherosclerosis in prolonged maintenance haemodialysis. N Engl f Med 1974; N 290 :697-701.

(Accepted 2 April 1981)

\title{
Metabolic studies in unaffected co-twins of non-insulin-dependent diabetics
}

\author{
A H BARNETT, A J SPILIOPOULOS, D A PYKE, W A STUBBS, J BURRIN, K G M M ALBERTI
}

\begin{abstract}
Forty-eight out of 53 non-insulin-dependent diabetic identical twin pairs were concordant for diabetes. In the five discordant pairs the diabetic twin had only recently been diagnosed. Oral glucose tolerance tests were carried out on the unaffected twins of the five pairs and on matched controls. Fasting concentrations of blood glucose $(5.5 \pm 0.6$ v $3.7 \pm 0.3 \mathrm{mmol} / \mathbf{1} ; 99 \cdot 1 \pm 10.8$ v $66.6 \pm 5.4$ $\mathrm{mg} / 100 \mathrm{ml}$ ), haemoglobin $A_{1}$ (mean $9 \cdot 1 \%$, range $8 \cdot 8-9 \cdot 2 \%$ v mean $7 \cdot 9 \%$, range $7 \cdot 4-8 \cdot 4 \%$, lactate, alanine, and glycerol $(0.090 \pm 0.017 \mathrm{v} 0.045 \pm 0.008 \mathrm{mmol} / \mathrm{l})$; and the lactate: pyruvate ratio were significantly higher in the
\end{abstract}

Diabetic Department, King's College Hospital, London SE5 9RS

A H BARNETT, MD, MRCP, research fellow

A J SPILIOPOULOS, MD, research fellow

D A PYKE, MD, FRCP, consultant physician

Department of Medicine, St Bartholomew's Hospital, London EC1A 7BE

W A STUBBS, PHD, MRCP, lecturer in medicine

Department of Clinical Biochemistry and Metabolic Medicine, Royal Victoria Infirmary, Newcastle upon Tyne NE1 4LP

J BURRIN, PHD, research fellow

K G M M ALBERTI, DPHIL, FRCP, professor of clinical biochemistry twins than controls. After glucose challenge blood glucose, lactate, alanine, and glycerol concentrations and lactate: pyruvate ratio were increased in the twins. Insulin response was severely impaired, being almost absent in four of the five twins.

The non-diabetic members of the discordant noninsulin-dependent diabetic pairs showed noticeable metabolic abnormalities which would later presumably deteriorate to frank diabetes. These findings, taken with the high concordance rate for non-insulin-dependent diabetic twins, suggest that non-insulin-dependent diabetes is predominantly, possibly entirely, inherited.

\section{Introduction}

Over the past 14 years we have studied identical twin pairs in $\stackrel{0}{\overparen{D}}$ whom one or both were diabetic. Of the 200 pairs seen to date, $\stackrel{?}{+}$ 147 were insulin-dependent and 53 non-insulin-dependent 0 diabetics. Of the 53 non-insulin-dependent pairs, all but five were concordant - that is, both twins were diabetic; in contrast, \& among the insulin-dependent pairs only about half were $\stackrel{\mathbb{Q}}{\varrho}$ concordant. In the five discordant non-insulin-dependent pairs the diabetic twin had been diagnosed only within the past three years, whereas the interval between diagnosis of diabetes in the first and second twins of the 48 concordant pairs in no case exceeded seven years. Hence it seemed likely that the five so 
far unaffected twins would develop diabetes, and we have studied them for evidence of metabolic abnormalities which might indicate the earliest changes of non-insulin-dependent diabetes.

\section{Patients and methods}

Five unaffected co-twins of non-insulin-dependent diabetics were studied. They were matched for age ( $46+7$ and $43+6$ years), body weight $\left(105+3\right.$ and $103+2 \%$ of average body weight $\left.{ }^{1}\right)$ and sex (three men, two women) with non-diabetic controls who had no family history of diabetes. No subjects were taking any drugs at the time of study and all were eating their usual diet.

An indwelling intravenous cannula was inserted into the antecubital vein and kept open with a slow infusion of saline. After 30 minutes' rest venous blood was taken 15 minutes and immediately before oral administration of $50 \mathrm{~g}$ glucose in $300 \mathrm{ml}$ water. Samples were subsequently taken at 15-minute intervals for one hour and at 30minute intervals for a further two hours. Serum was used for radioimmunoassay of insulin, ${ }^{3}$ and perchloric acid extract of blood for assay of glucose, lactate, pyruvate, alanine, glycerol, and 3-hydroxybutyrate concentrations by an automated enzymatic fluorometric technique. ${ }^{34}$ Fasting blood haemoglobin $A_{i}$, serum cholesterol, and triglyceride concentrations were also measured. Haemoglobin $A_{1}$ was measured by a macrocolumn technique using Bio-Rex 70 with 200-400-mesh sodium form ion-exchange resin (Bio-Rad, Richmond, California). Cholesterol and triglyceride concentrations were measured by standard automated enzymatic techniques.

Results are expressed as means $\downarrow$ SEM and were compared using the Wilcoxon $U$ test $; p<0.05$ was accepted as significant.

\section{Results}

The table shows the blood lactate, pyruvate, alanine, glycerol, and 3-hydroxybutyrate concentrations before and after the oral glucose tolerance test.

\section{FASTING VALUES}

Mean blood glucose concentration (at -15 and 0 minutes) was significantly increased in the non-diabetic twins compared with the controls $(5.5 . \pm 0.6 v 3.7 .0 .3 \mathrm{mmol} / 1 ; 99.1 \pm 10.8 v 66.6 \pm 5.4 \mathrm{mg} /$ $100 \mathrm{ml}$ ) (fig 1). Haemoglobin $\mathrm{A}_{1}$ values were also higher in the twins (mean $9.1 \%$, range $8 \cdot 8-9.2 \%$ ) than in the controls (mean $7.9 \%$, range $7 \cdot 4-8 \cdot 4 \%)(p<0 \cdot 01)$. Fasting serum insulin concentrations, however, were not significantly different between the two groups (fig 2).
Concentrations of blood lactate, alanine, and glycerol and the actate:pyruvate ratio were higher in the twins than in the controls (table). Pyruvate and 3-hydroxybutyrate concentrations were, however, similar in the two groups, as were the serum cholesterol and triglyceride concentrations.

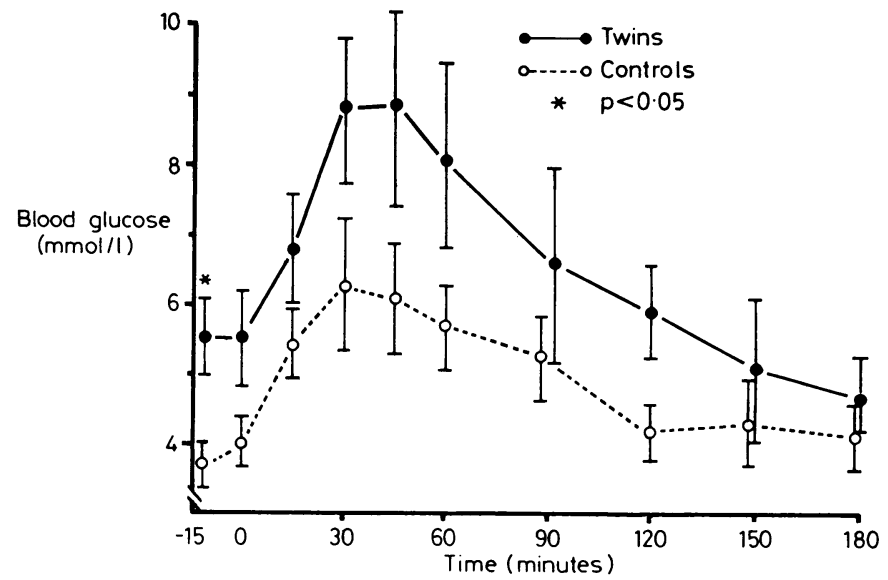

FIG 1-Mean blood glucose concentrations ( \pm SEM) fasting and after $50 \mathrm{~g}$ oral glucose challenge in twins and controls.

Conversion: SI to traditional units-Glucose: $1 \mathrm{mmol} / 1 \approx 18 \mathrm{mg} / 100 \mathrm{ml}$.

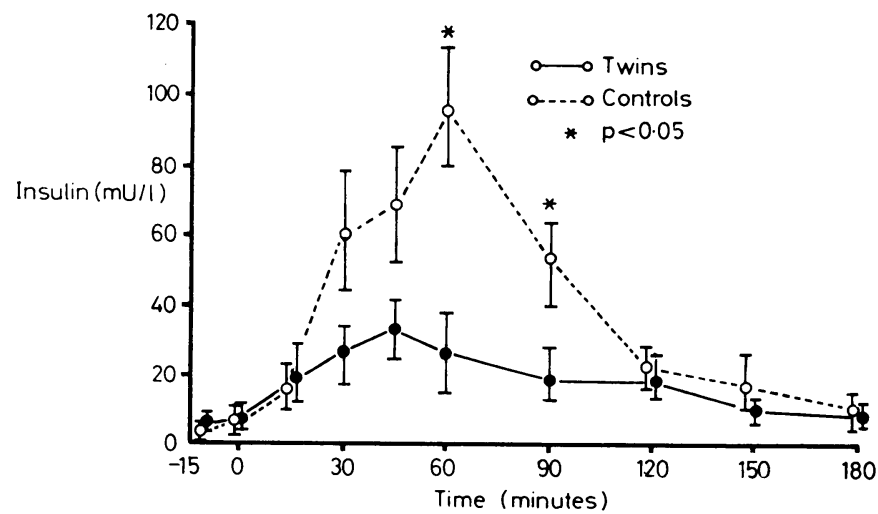

FIG 2-Mean serum insulin concentrations ( $t$ SEM) fasting and after $50 \mathrm{~g}$ oral glucose challenge in twins and controls.

Mean $\pm S E M$ concentrations of blood metabolites before and after $50 \mathrm{~g}$ oral glucose tolerance test in five non-diabetic co-twins of non-insulin-dependent diabetic and five matched controls (fasting triglyceride and cholesterol concentrations also shown)

\begin{tabular}{|c|c|c|c|c|c|c|c|c|c|c|c|c|}
\hline & & & & \multirow{2}{*}{ Fasting } & \multicolumn{8}{|c|}{ Time after oral glucose (minutes) } \\
\hline & & & & & 15 & 30 & 45 & 60 & 90 & 120 & 150 & 180 \\
\hline Lactate $(\mathrm{mmol} / \mathrm{l})$ & $\cdots$ & .. & $\begin{array}{l}\text { Twins } \\
\text { Controls }\end{array}$ & $\begin{array}{l}1 \cdot 300 \\
\pm 0 \cdot 300^{*} \\
0.700 \\
\pm 0.100\end{array}$ & $\begin{array}{c}1 \cdot 163 \\
\pm 0 \cdot 141 \\
0.732 \\
\pm 0 \cdot 185\end{array}$ & $\begin{array}{c}1 \cdot 229 \\
\pm 0 \cdot 170 \\
0.743 \\
\pm 0.170\end{array}$ & $\begin{array}{l}1 \cdot 216 \\
\pm 0 \cdot 110 \\
0.842 \\
\pm 0 \cdot 165\end{array}$ & $\begin{array}{c}1.345 \\
\pm 0.124 \\
0.950 \\
\pm 0.153\end{array}$ & $\begin{array}{l}1.221 \\
\pm 0.081^{*} \\
0.895 \\
\pm 0.098\end{array}$ & $\begin{array}{c}1.179 \\
\pm 0.080^{*} \\
0.760 \\
\pm 0.103\end{array}$ & $\begin{array}{l}1 \cdot 242 \\
\pm 0 \cdot 150^{*} \\
0.727 \\
\pm 0.115\end{array}$ & $\begin{array}{c}1 \cdot 037 \\
\pm 0 \cdot 126 \\
0 \cdot 764 \\
\pm 0 \cdot 140\end{array}$ \\
\hline Alanine $(\mathrm{mmol} / \mathrm{l})$ & $\cdots$ & .. & $\begin{array}{l}\text { Twins } \\
\text { Controls }\end{array}$ & $\begin{array}{l}0.372 \\
\pm 0 \cdot 029^{*} \\
0.248 \\
\pm 0.050\end{array}$ & $\begin{array}{c}0.389 \\
\pm 0.024 \\
0.248 \\
\pm 0.045\end{array}$ & $\begin{array}{c}0.427 \\
\pm 0.054 \\
0.258 \\
\pm 0.053\end{array}$ & $\begin{array}{c}0.393 \\
\pm 0.027 \\
0.255 \\
\pm 0.059\end{array}$ & $\begin{array}{c}0.408 \\
\pm 0.038^{*} \\
0.258 \\
\pm 0.038\end{array}$ & $\begin{array}{c}0.370 \\
\pm 0.030^{*} \\
0.252 \\
\pm 0.035\end{array}$ & $\begin{array}{l}0.384 \\
\pm 0.027^{*} \\
0.278 \\
\pm 0.033\end{array}$ & $\begin{array}{c}0.370 \\
\pm 0.040^{*} \\
0.249 \\
\pm 0.024\end{array}$ & $\begin{array}{l}0.347 \\
\pm 0.026^{*} \\
0.256 \\
\pm 0.031\end{array}$ \\
\hline Glycerol ( $\mathrm{mmol} / \mathrm{l})$ & . & . & $\begin{array}{l}\text { Twins } \\
\text { Controls }\end{array}$ & $\begin{array}{l}0.090 \\
\pm 0.017^{*} \\
0.045 \\
\pm 0.008\end{array}$ & $\begin{array}{l}0.067 \\
\pm 0.004 \\
0.043 \\
\pm 0.010\end{array}$ & $\begin{array}{l}0.059 \\
\pm 0.004^{*} \\
0.036 \\
\pm 0.007\end{array}$ & $\begin{array}{l}0.050 \\
\pm 0.005^{*} \\
0.030 \\
\pm 0.005\end{array}$ & $\begin{array}{l}0.057 \\
\pm 0.003^{*} \\
0.030 \\
\pm 0.006\end{array}$ & $\begin{array}{c}0.046 \\
\pm 0.004 \\
0.033 \\
\pm 0.005\end{array}$ & $\begin{array}{l}0.053 \\
\pm 0.003^{*} \\
0.040 \\
\pm 0.001\end{array}$ & $\begin{array}{c}0.066 \\
\pm 0.005^{*} \\
0.037 \\
\pm 0.006\end{array}$ & $\begin{array}{l}0.063 \\
\pm 0.004^{*} \\
0.040 \\
\pm 0.007\end{array}$ \\
\hline 3-Hydroxybutyrate & $(\mathrm{mn}$ & & $\begin{array}{l}\text { Twins } \\
\text { Controls }\end{array}$ & $\begin{array}{c}0.027 \\
+0.006 \\
0.050 \\
+0.030\end{array}$ & $\begin{array}{c}0.033 \\
\pm 0.007 \\
0.050 \\
\pm 0.032\end{array}$ & $\begin{array}{l}0.026 \\
\pm 0.004 \\
0.045 \\
+0.029\end{array}$ & $\begin{array}{c}0.019 \\
\pm 0.004 \\
0.021 \\
\pm 0.010\end{array}$ & $\begin{array}{l}0.016 \\
\pm 0.003 \\
0.015 \\
\pm 0.005\end{array}$ & $\begin{array}{l}0.011 \\
\pm 0.002 \\
0.012 \\
\pm 0.005\end{array}$ & $\begin{array}{l}0.008 \\
\pm 0.002 * \\
0.021 \\
\pm 0.004\end{array}$ & $\begin{array}{l}0.010 \\
\pm 0.002 \\
0.021 \\
\pm 0.006\end{array}$ & $\begin{array}{l}0.011 \\
\pm 0.002^{*} \\
0.041 \\
\pm 0.015\end{array}$ \\
\hline Lactate:pyruvate & . & - & $\begin{array}{l}\text { Twins } \\
\text { Controls }\end{array}$ & $\begin{array}{c}14 \cdot 7+1 \cdot 8^{*} \\
7 \cdot 0 \pm 1 \cdot 0\end{array}$ & $\begin{aligned} 14.4 & \pm 1.0^{*} \\
6.9 & \pm 0.9\end{aligned}$ & $\begin{array}{c}12.8 \pm 0.8^{*} \\
7.0 \pm 0.9\end{array}$ & $\begin{array}{c}13 \cdot 2 \pm 0.4^{*} \\
7.8 \pm 1.3\end{array}$ & $\begin{array}{c}13 \cdot 9 \pm 0 \cdot 9 * \\
8 \cdot 2 \pm 1 \cdot 0\end{array}$ & $\begin{array}{c}14.0 \pm 0.5^{*} \\
8.6 \pm 1.0\end{array}$ & $\begin{array}{c}14 \cdot 7 \pm 0.6^{*} \\
6.7 \pm 0.3\end{array}$ & $\begin{array}{c}16 \cdot 3 \pm 2.7 * \\
7.5 \pm 0.7\end{array}$ & $\begin{aligned} 16.1 & \pm 1.9 * \\
7.8 & \pm 0.7\end{aligned}$ \\
\hline Triglycerides $(\mathrm{mm}$ & $1 / 1)$ & & $\begin{array}{l}\text { Twins } \\
\text { Controls }\end{array}$ & $\begin{array}{l:l}1.5 & 0.4 \\
0.9 & 0.3\end{array}$ & & & & & & & & \\
\hline Cholesterol (mmol & & .. & $\begin{array}{l}\text { Twins } \\
\text { Controls }\end{array}$ & $\begin{array}{l}5 \cdot 1+0.4 \\
5 \cdot 0 \pm 0.3\end{array}$ & & & & & & & & \\
\hline
\end{tabular}

*Significantly different from control value $(\mathrm{p}<0.05)$

Conversion: SI to traditional units-Lactate: $1 \mathrm{mmol} / 1 \approx 9 \cdot 0 \mathrm{mg} / 100 \mathrm{ml}$. Alanine: $1 \mathrm{mmol} / 1 \approx 8.9 \mathrm{mg} / 100 \mathrm{ml}$. Glycerol: $1 \mathrm{mmol} / 1 \approx 9 \cdot 2 \mathrm{mg} / 100 \mathrm{ml}$. $3-\mathrm{Hydroxybutyrate:}$ $1 \mathrm{mmol} / 1 \approx 10.4 \mathrm{mg} / 100 \mathrm{ml}$. Triglyceride: $1 \mathrm{mmol} / 1=88.5 \mathrm{mg} / 100 \mathrm{ml}$. Cholesterol: $1 \mathrm{mmol} / 1=38.7 \mathrm{mg} / 100 \mathrm{ml}$. 


\section{RESPONSES TO ORAL GLUCOSE TOLERANCE TEST}

Although blood glucose concentrations at any one time after the glucose load were not significantly different between the two groups, mean values were increased in the twins $(6.5 \pm 0.1 \mathrm{mmol} / 1 v 4.9+0.4$ $\mathrm{mmol} / 1(117 \cdot 1 \pm 1.8 v 88.2 \pm 7.2 \mathrm{mg} / 100 \mathrm{ml}) ; \mathrm{p}<0.05)$ (fig 1). The serum insulin response was greatly diminished in the twins (fig 2), four of the five showing an almost flat response, and the remaining one nearly normal insulin secretion. Blood lactate, alanine, and glycerol concentrations were significantly higher in the twins than in the controls. Pyruvate values were similar in the two groups, but the lactate:pyruvate ratio was higher in the twins. 3-Hydroxybutyrate concentrations remained low in the twins.

\section{Discussion}

Few data are available on the early metabolic changes of non-insulin-dependent diabetes. All attempts to characterise prediabetes have been in relation to insulin-dependent diabetes and were not relevant to this study. ${ }^{5-?}$

All the non-diabetic twins of the five discordant non-insulindependent pairs showed metabolic abnormalities, particularly a striking insulin deficiency similar to that seen in established non-insulin-dependent diabetes. ${ }^{8}$ ' In four out of five there was a negligible response to a glucose challenge. Rises in blood lactate, alanine, and glycerol concentrations were consistent with increased gluconeogenesis and lipolysis. The circulating blood ketone bodies, as represented by 3-hydroxybutyrate values, however, were not increased. Non-esterified fatty acids may be increased in prediabetes, ${ }^{8}$ and the low 3-hydroxybutyrate values in the twins suggest that there was enough insulin activity to suppress hepatic ketogenesis, which is extremely sensitive to its action, but not enough to produce normal intermediary metabolism.

There were relatively small changes in blood glucose concentrations. In the twins these were higher than in the controls but still within the normal range; the difference, however, was significant only in the fasting state. The haemoglobin $A_{1}$ value in the twins was at or slightly above the upper limit of our normal range and there was no overlap between them and controls. This suggests that even slight hyperglycaemia is reflected by a raised haemoglobin $A_{1}$ value and that this may therefore be a good indicator of early diabetes.

These results also suggest that the development of noninsulin-dependent diabetes is preceded by detectable metabolic abnormalities and that blood glucose values may be one of the least sensitive indicators; impairment of insulin response seems to be much better. Concentrations of lactate, alanine, and glycerol are also better discriminators between twins and 3 controls than glucose values.

Of our 53 non-insulin-dependent diabetic pairs of identical $C$ twins, 48 were concordant. The non-diabetic members of the $\widehat{\Omega}$ remaining five discordant pairs showed definite metabolic $\overline{ }$ abnormalities which would presumably later deteriorate ${ }_{\mathbb{D}}^{D_{D}}$ further to frank diabetes. These findings strengthen our ${ }^{\infty}$ hypothesis that non-insulin-dependent diabetes is predominantly, perhaps entirely, inherited. ${ }^{10} 11$

We thank the physicians and other colleagues in the British음 Diabetic Association who made this study possible, and the twins $\bar{O}$ themselves. We also thank the BDA for financial support. AHB is $\frac{\bar{m}}{10}$ supported by the MRC.

Requests for reprints should be addressed to Dr D A Pyke, King's College Hospital, London SE5 9RS

\section{References}

1 Metropolitan Life Assurance Company. New weight studies for men and women. Statistical Bulletin 1959;40:3.

2 Soeldner J, Slone D. Critical variables in radioimmunoassay of serum insulin using the double antibody technique. Diabetes 1965;14:771-9. Y

${ }^{3}$ Foster KJ, Alberti KGMM, Hinks L, et al. Blood intermediary metabolite. and insulin concentrations after an overnight fast; reference ranges for $\vec{\sigma}$ adults, and interrelations. Clin Chem 1978;24:1568-72.

${ }^{4}$ Lloyd B, Burrin J, Smythe P, Alberti KGMM. Enzymatic fluorometric ${ }^{\circ}$ continuous-flow assays for blood glucose, lactate, pyruvate, alanine,, glycerol and 3-hydroxybutyrate. Clin Chem 1978;24:1724-9.

5 Steinke J, Soeldner JS, Camerini-Davalos RA, Renold AE. Studies on ${ }^{N}$ serum insulin-like activity in prediabetes and early overt diabetes. Diabetes 1963;12:502-7.

6 Camerini-Davalos RA, Caulfield JB, Rees SB, Lozano-Castaneda $\mathrm{O}, \rightarrow$ Naldjian S, Marble A. Preliminary observations on subjects with $\bigcup_{\infty}$ prediabetes. Diabetes 1963;12:508-18.

${ }^{7}$ Kahn CR, Soeldner JS, Gleason RE, Rajas L, Camerini-Davalos RA, Marble A. Clinical and chemical diabetes in offspring of diabetico couples. N Engl Y Med $1969 ; 281: 343-7$.

${ }^{8}$ Cerasi E, Luft R, Efendic S. Decreased sensitivity of the pancreatic beta cells to glucose in prediabetic and diabetic subjects. Diabetes 1972;0 21 :224-34.

- Colwell JA, Lein A. Diminished insulin response to hyperglycaemia in prediabetes and diabetes. Diabetes 1967;16:560-5.

10 Pyke DA. Diabetes: the genetic connections. Diabetologia 1979;17:333-43. 윽

11 Barnett AH, Eff C, Leslie RDG, Pyke DA. Diabetes in identical twins. A study of 200 pairs. Diabetologia $1981 ; 20: 87-93$.

(Accepted 2 April 1981)
ONE HUNDRED YEARS AGO An inquest was held on Tuesday last, by Dr Diplock, on the body of Miss Angela Wallsworth, aged 33, matron at the Metropolitan and City Police Orphanage at Twickenham, of which we have obtained particulars of great toxicological interest. It appears that she had complained of a cold in the head in the presence of Dr Webster, who remarked that camphor and aconite, in drop doses, were useful in the earlier stages of this complaint. From the evidence of a Miss Daines, who had slept in deceased's room as a guest, it appeared that, before going to bed, deceased took something in a tumbler and water. She also gave Miss Daines some, telling her it was good for a headache. Soon afterwards, Miss Daines felt very restless, and had a strange numbness in her hands and arms; and, finding the deceased in an even worse state, she spoke to her. Deceased said that she felt as if she were swelling, and would get out of bed and ask one of the nurses to give her some coffee. She left the room to do so, and did not return. Miss Daines was herself so ill from the effects of the aconite, of which Miss Wallsworth had given a teaspoonful, that she fainted whilst giving her evidence. Mr Netherclift said that, when called to Miss Wallsworth, between two and three on Sunday morning, she was gasping for breath, with her mouth wide open and her tongue protruding. Her eyes were fixed on vacancy, and the pupils were much dilated. He asked her what she had taken, and she gasped out "Aconite." He administered an emetic of mustard, which induced copious vomiting. Diffusible stimulants, such as ammonia and brandy, were also given. Heat was applied to the extremities and cardiac region. He then administered, at intervals, three subcutaneous injections of from ten to fifteen minims of tincture of digitalis. Galvanism was also applied in the region of the heart. $\mathrm{Dr}_{\mathscr{O}}$ Hamilton Bland was then called in in consultation; and three sub- $\rightarrow$ cutaneous injections of brandy were given. Frequent inhalations of 0 ammonia were adopted. The patient was then completely insensible, and pulseless. Artificial respiration was maintained, without inter- $O$ mission, for two hours; but, beyond slight reflex action of the ${ }_{\omega}^{N}$ laryngeal muscles, there were no symptoms of returning life. The juryo found a verdict of "Death by misadventure"; and conveyed, through their foreman, to Mr Netherclift and Dr Hamilton Bland, the following resolution, which had been passed unanimously, "The jury wish too express their high appreciation of the painstaking attention and sustained efforts, so promptly resorted to by the medical gentlemen in attendance on the deceased; and their conviction, that nothing that science or skill could do was left undone in their endeavour to avert? the fatal issue." It was understood that the unfortunate lady had taken three teaspoonsful of Fleming's tincture of aconite, from a bottleo which she had filled in the dispensary. She survived the fatal dose four hours. There was a marked improvement in the pulse after each injection of digitalis. We understand that Miss Daines is still in at critical condition. (British Medical fournal, 1881.) 